\title{
Human Security in the Republic of North Macedonia: A Necessity and a Challenge
}

\section{Abstract}

One of the most popular concepts nowadays is the concept of human security. It is a concept that has attempted to redefine the global security agenda and is perceived as a revolutionary act that shifts the focus of interest from the security of states to the security of the person, the security of the individual in the society. The idea of the concept is to establish human security by monitoring the indicators of human life disruption (economic security - freedom from poverty, unemployment; personal security, political security, etc.). The aim of the paper is to prove the necessity to develop the human security concept in the Republic of North Macedonia through scientific elaboration and practical implementation. Therefore, the content of this paper is meant to analyze threats to human security, specifically through examples of poverty and unemployment, to differentiate separate categories of human insecurity and to show/point out that the concept of human security should be comprehensive and directed to the freedom from fear and freedom from poverty.

Keywords: security, threats, human security, poverty, unemployment

1 Marina Mitrevska, Ph.D. Full Professor at the Institute of Security, Defence and Peace, Faculty of Philosophy, University of "Ss. Cyril and Methodious" - Skopje, the Republic of North Macedonia. E-mail:marinamitrevska@yahoo.com 


\section{Human Security in the Republic of North Macedonia: A Necessity and a Challenge}

\section{Introduction}

Nowadays, the security paradigm is faced with challenges, problems, threats and processes, and the 37 I Page new millennium, compared to the past, has significantly gained new specifics and features. In this context, important objective factors (geostrategic, militarypolitical, security, environmental and other factors) that determine the security realities in individual states have also considerably changed (Mitrevska 2016: 21). All of these changes are strongly influenced by the processes of globalization, which, in turn, put countries in front of new challenges and problems. In these conditions, it has become evident that the enthusiasm for the construction of the New World Order and the peace dividend after the fall of the Berlin Wall lasted very shortly and the new millennium humanity brought with it the legacy of old problems and methods of solving the most pressing global, regional or national problems. In those circumstances, if anything changes, it is the rhetoric that justifies the actions and concepts that should demonstrate (and prove) a level of innovative and creative thinking among the most important actors (Ванковска, 2006: 413-414). This time, the most interesting are the concept of human security, conflict management, humanitarian interventions and so on. There is no doubt that one of the most popular and, at the same time, the most influential concepts today is the concept of human security (Burges, 2007: 31). There are a number of reasons for this. First, the generic link between the concept of human security and that of security understood in the most general sense. In fact, they are closely related, and the basic link that connects them is the 'process of securitization'. Second, human security shifts the focus of interest from traditional security to the security of the person, the security of the individual in the society. Third, human 


\section{European Human}

security recognizes that personal protection of the individual and preservation of their integrity do not come primarily from the protection of the state as political elite, but from the approach to personal well-being and quality of life. Fourth, it is increasingly clear that the needs faced by the common man should be recognized, which reflects a growing consensus. Hence, security can no longer be narrowly defined as the absence of armed conflict, among or within states, because the pursuit of this variant would mean ignoring serious problems such as massive human rights infringement, forced large-scale displacement of civilians, terrorism and environmental disasters as direct threats to human security. Even in today's practice, the consequences of such direct threats to human security comprise far more than absence of violent conflict. They include human rights, affordable education, health care, and the belief that every individual has the opportunity and chance to fulfil their potential. Every step in this direction is also a step towards reducing poverty and increasing economic growth.

Thus, it has become obvious that from the people's point of view, security represents protection from disease, hunger, unemployment, poverty, crime, environmental endangerment and so on. That is why the view is justified and the key questions asked in security analyses are the following, which further determines not only the discourse, but also the solutions to the problems posed (Møller, 2000: 37). Security for whom? The answer is that human security implies security of the individual. While to the question: Security for what values?, the explicit answer is that human security values include an acceptable quality of life and guarantee of basic human rights. However, it, at least, implies basic needs such as stable economic development, human rights and fundamental freedoms, rule of law, stable development and social equality. That is why we can argue that the fundamental values of human security are freedom from fear, and freedom from lack of equal opportunities. In particular, the central value in the conception of human 
security is the liberation from threats to human rights, security and human life.

Regarding the question: What are the threats to these core values?, we could, above all, list the income gap between the rich and poor countries, internal conflicts, ethnic conflicts and migration, transnational crime, environmental degradation, insufficient economic and volatile development, and so on.

And finally, regarding the question: What means of security?, we can critically warn that human security can be achieved through development, not ... weapons. In particular, in order to revive the new security concept, it is necessary to take some rather radical steps: the concept of human development, which will emphasize equality and continuity, building peace that will underpin the human security agenda, and so on.

Hence, Asberg and Wallensteen's ${ }^{1}$ view is quite justified that the determination of security content depends on three essential elements, namely: core values (relating to aspects of what we want to provide), threats are the ones that show what challenges and dangers these values and capabilities are exposed to (resources and actors that can tackle threats, that is, guarantee security).

In this context, it can be concluded that, according to these authors, the understanding of security is not possible without considering all three elements together, as well as their interrelationship. Hence, the ultimate goal of human security should be sought in the overlap of conditions for the development of individual abilities and the creation of a society free from structural violence, such as poverty and discrimination. In other words, we should strive to build a society that respects individual human rights, economic development and social justice. Certainly, these are goals that cannot be achieved by the use of military means and militarized methods, but only by the development of the society through all spheres (economic, social, human rights, rule of law, etc.).

1 See more in: Asberg \& Wallensteen, 1998: 169.

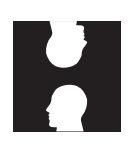




\section{European Human \\ Journal of Security}

For the developing countries, such as the Republic of North Macedonia, economic growth is an imperative rather than an alternative due to several reasons. First, achieving economic growth is important in order to address the challenge of increased poverty, as well as for the accumulation of the necessary resources for human development. Second, human development is not possible if the foundations of human security are unstable. This is due to the fact that human security refers to a number of security types, which mutually correlate closely, such as economic, health, political, environmental, food security and so on.

\section{Challenges Related to Human Security in the Republic of North Macedonia}

The question of how much we, as individuals, are truly safe and free in the Republic of North Macedonia will be raised in the context of the analysis of the poverty and unemployment index. To begin with (at least slightly) a more substantial elaboration of poverty and unemployment, one must first explain the essence of two things: first, poverty is a multidimensional and complex phenomenon. Second, persistently high unemployment rate is a key indicator of poverty in the country. Citizens, above all, want to live a better life. In that sense, the most important goal of economic policy is always - except in case of war, natural disasters, and the like - to increase the standard of living or improve material well-being (Uzunov 2019: 78).

However, a further explanation is needed here - poverty is more than purely material aspect and fundamentally represents the lack of opportunities for human development. Since 2010, the Laeken indicators have been applied in the Republic of Macedonia for its measurements, and they consider poor those persons whose income is less than 60 percent of the median equivalent value. Although there is a definition that is compatible with the European standards, it still focuses on income shortages and also includes living conditions such as: lack of home, clean water, access to electricity, sanitation, schooling conditions, health care, 


\section{European Human}

transportation and the like. According to the data, in 2015, the poverty rate in the Republic of Macedonia was $21.5 \%$ (State Statistical Office of the Republic of North Macedonia, 2019), while in 2016 it was $21.9 \%$. In 2017, the poverty rate in the Republic of Macedonia was $22.2 \%$ and in 2018 , it was $21.8 \%$. A clearer picture of poverty in North Macedonia can be obtained from the analysis of poverty and social exclusion indicators (final data 2013-2018).

- At-risk-poverty rate of population in 2013 was $24.2 \%$, in 2014 it was $22.1 \%$, in 2015 it was $21.5 \%$, in 2016 it was $26.9 \%$, and in 2017 it was $22.2 \%$, and in 2018 it was $21.8 \%$.

- Number of persons below at-risk-of-poverty threshold, in thousand persons in 2013 was 504.2, in 2014 it was 457.2, in 2015 it was 445.2, in 2016 it was 453.2, and in 2017 it was 460.3 (State Statistical Office of the Republic of North Macedonia).

The above stated indicators show that out of $21.5 \%$ in 2015 , the poverty rate in 2016 increased by $0.4 \%$. There is a slight decrease in the poverty rate by $0.3 \%$ in 2017 .

The reasons for the high poverty rate are partly due to socio-economic factors, the lengthy transition process, low economic activity and high unemployment rate. Furthermore, factors related to the lack of strategic measures, operational plans and actions to reduce poverty also have an impact. Despite a slight decline, there is still a high poverty rate in the Republic of North Macedonia. These data show that the state should pursue an active policy aimed at reducing poverty and increasing the quality of life.

Therefore, in 2010, the Government of the Republic of North Macedonia adopted the National Strategy for Poverty Reduction and Social Exclusion in the Republic of Macedonia for the period 2010-2020. The National Strategy outlines the various aspects and impacts of the phenomena expressing poverty and social exclusion. The main strategic goal of poverty reduction and social exclusion in the Republic of Macedonia aims at the following: 


\section{European Human \\ Journal of Security}

- Reduction of poverty and social exclusion in the Republic of Macedonia through better utilization and strengthening of the available human and material resources;

- Improving the living, working and social conditions of all citizens;

- Systemic and institutional interaction aimed at faster development, higher standards, better quality of life and development of mechanisms for social inclusion of vulnerable categories, and, above all, the vulnerable categories of citizens in the local context.

Moreover, the goals, measures, and activities in the Strategy are aimed at achieving the main strategic goal, aligning policies in specific areas of inclusive growth, and concentrating on the following areas: employment and entrepreneurship strengthening, adapting education to the labour market, social and child protection and building a new social model, promoting health care and long-term care, transport, communications and housing, activating and strengthening local authorities and supporting vulnerable groups.

Equally important are the basic principles defined in the National Strategy for Poverty Reduction and Social Exclusion of the Republic of North Macedonia, and they are based on integrity, which implies a multidimensional problem that requires a multidimensional solution. Furthermore, they include prevention, understanding of what can be undertaken, inclusion and commitment, which in turn implies joint efforts of central and local government, public institutions, business community and relevant non-governmental organizations in identifying the content of specific policy development needs, programs and projects. It should be done separately for vulnerable groups and it should consider the encouragement needed to successfully tackle social problems, so it is necessary for the government to encourage all social factors and create a culture of 'selfhelp' in individuals and groups. 


\section{European Human}

The next step of North Macedonia that deserves attention in the fight to reduce poverty and promote an inclusive society is the Macedonian Anti-Poverty Platform, which, as a member of EAPN has introduced a measure called 'Minimum Dignified Income' (MDI) (Македонска платформа против сиромаштија, 2012). This European Anti-Poverty Network (EAPN) is campaigning for the introduction of an adequate minimum income measure under the motto 'Adequate Minimum Income. Everyone deserves a dignified life.' Minimum dignified income is a payment by the state to people who cannot work or have no access to decent work. This contributes to well-being and dignified life, representing the key instrument in preventing poverty and social exclusion, as long as resources are sufficient to get people out of poverty.

Next issue for an argumentative debate regarding the issue of human security in the Republic of North Macedonia is the unemployment. The fact is that the Republic of North Macedonia is in the group of countries with the highest unemployment rate in Europe. The unemployment is mainly structural with a high rate of long-term unemployment and a low level of education among the unemployed people. Specifically, the percentage of long-term unemployment in 2015 was $81.5 \%$, in 2016 it was $80.9 \%$, in 2017 it decreased slightly, and it was $77.9 \%$. Whereas, the long-term unemployment rate in 2015 was $21.3 \%$, in 2016 it was $19.2 \%$, and in 2017 it was $17.4 \%$. From the data analysis we can see that although the unemployment rate decreases, the percentage of long-term unemployment is significantly high (State Statistical Office of the Republic of North Macedonia). 


\section{European Human \\ Journal of Security}

Page I 44

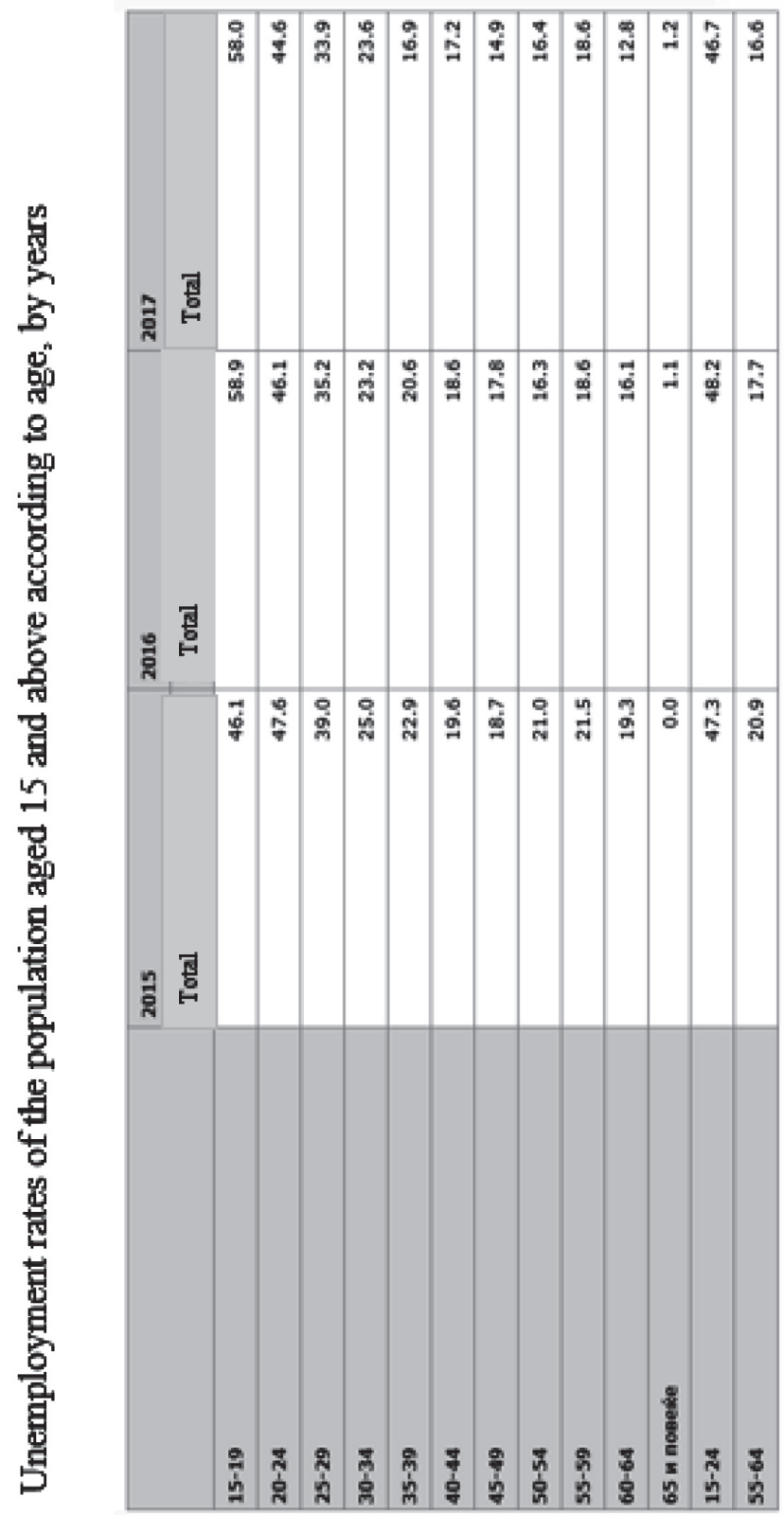

Source: State Statistical Office of the Republic of North Macedonia (2019) ${ }^{2}$

2 The total unemployment rate represents the share of unemployed persons aged 15-64 in the total labour force. The labour force comprises the total number of employed and unemployed

Issue 3 / 2019

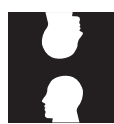




\section{European Human}

The improvement of employment in the Republic of North Macedonia depends primarily on theimplementation of macroeconomic policy and stronger economic growth and investment. By combining existing activities with certain new measures, the Republic of North Macedonia is striving to control the problem of unemployment, poverty and inequality. Therefore, in 2015, the Government of the Republic of Macedonia adopted the National Employment Strategy for the period 2016-2020. ${ }^{3}$ The main objective of the National Employment Strategy of the Republic of Macedonia 2020 is "to increase employment, quality of jobs and productivity, with a particular focus on vulnerable population groups" (National Employment Strategy in the Republic of Macedonia, 2015). According to this Strategy, several activities should be fulfilled such as: increasing the effectiveness and efficiency of employment policy, with particular support for vulnerable categories of population improving the capacity of the private sector to create jobs, education producing knowledge and skills according to the need of the employers. In addition, the Government of the Republic of North Macedonia has set out a number of measures and has undertaken certain activities ${ }^{4}$ aimed at economic growth of the country, opening new jobs, improvement of living standards, which should directly influence the improvement and recognition of the concept of human security and human development.

The latest reports from the National Bank of the Republic of North Macedonia (as in the period of writing the paper) show that exactly in 2018 we have a record foreign direct investments of EUR 625 million, almost 4 times more than in 2017 and more than in 2012, 2013

persons. The indicator is presented as the total unemployment rate, by age group, according to the number of unemployed persons in relation to the overall work force of the same target group.

3 The Strategy is prepared with the support of three international institutions: The International Labour Organization (ILO), the World Bank and the UNDP.

4 The official state policy relies on the following postulates: education (compulsory primary and secondary education, etc.); health care (renovated and new hospitals, new equipment, etc.) employment (support by the Government through the Employment Agency with the project for self-employment, creating conditions for foreign companies to invest their capital in our country, thus employing the unemployed citizens). 


\section{European Human}

and 2014 all together! This is just one signal that, in the coming period, government measures should contribute to poverty reduction and unemployment in the Republic of North Macedonia.

\section{Conclusion}

Through the example of poverty and unemployment, we have captured only a fraction of the concept of human security in the Republic of North Macedonia. Insufficient, yet necessary to point out through these two examples is that human security must be based on fundamental understanding and that the Government of North Macedonia must maintain the primary role of ensuring the survival, life and dignity of its citizens. Therefore, the concept of human security is an invaluable tool in helping governments identify critical and natural threats to the well-being of their people and the stability of their sovereignty. Certainly, all this can help the government and the international community make better use of their resources, develop strategies and strengthen the protection and authorization framework needed to ensure people's safety and promote peace and stability at every level: locally, nationally, regionally and internationally.

In this respect, research proves that security is a social construct and a consequence of factors acting at different levels (locally, nationally, regionally and internationally) and affecting (in)security. It is this characteristic that gives it the breadth so that security is perceived as a shared value and implies that both the state and individuals are equally important security entities. Hence, human security is based on all progressive ideas and concepts created in the course of humankind, and the innovation it offers should be sought in the altered conditions in which the individual exists. Therefore, one should not forget the "legitimate care of ordinary people who seek security in their daily lives". This is the case because people are at the centre of human security, or, to put it in another way, it is an imperative to build 'one society for all', but only if we take into account the genuine description of security 'freedom from fear' and 'freedom from want'. 


\section{REFERENCES}

Asberg, CJ \& Wallensteen, P. (1998). New threats and new security: The post-Cold War debate revisited. In P. Wallensteen (Ed.), Preventing violent conflicts: Past 47 I Page records and future challenges. Uppsala University.

Burges J.P. (2007). Non-military security challenges. In Craig A. Snyder, (Ed.), Contemporary Security and Strategy (pp. 60-78). London: Palgrave.

Македонска платформа против сиромаштија (2012). Минимален достоинствен приход. Available at: http://www.mpps.org.mk/index.php?option=com_ content $\&$ view $=$ article\&id=202\&Itemid $=161$

Møller, B. (2000). National, societal and human security: A general discussion with a case study from the Balkans. Copenhagen Peace Research Institute.

Митревска, М. (2016). Хумана безбедност. Филозофски факултет, Скопје. Република Македонија.

National Employment Strategy in the Republic of Macedonia. (2015). Ministry of Work and Social Politics. (http:// www.mtsp.gov.mk/content/pdf/strategii/Nacionalna\%20Strategija\%20za\%20Vrabotuvane $\% 20$ na $\% 20$ Republika\%20Makedonija\%20za\%20Vlada\%20 16102015.pdf).

State Statistical Office of the Republic of North Macedonia. (2019). Available at: http://www.stat.gov.mk/Default_en.aspx

The European Anti-Poverty Network (EAPN). Available at: https://www.eapn.eu/who-we-are/what-is-eapn/

Узунов, В. (2019). Патот од економска отвореност до меѓународна економска интеграција. Предизвици: Пост-преспанска Северна Македонија и предизборна Европа, бр.1/03/2019. Skopje: Fridrich Ebert Stiftung.

Ванковска, Б. (2006). Хумана безбедност, меѓу науката и глобалната политика, Годишен зборник на Филозофскиот факултет, Скопје, Република Македонија.

Wallensteen, P. (1998). Preventing violent conflicts: Past record and future challenges. Uppsala University. 


\title{
Identifying Evacuation Assembly Points: An Application at Latsia, Nicosia, Cyprus
}

\author{
Savvas Chrysoulidis ${ }^{1}$
}

This article is based on a presentation delivered at the $4^{\text {th }}$ International Academic Conference on Human Security, Belgrade, organized by the Faculty of Security Studies, University of Belgrade, 2-3 November 2018. The author is grateful for the feedback received during the conference.

\section{Abstract}

The occurrence and magnitude of real-world threats and challenges are difficult to predict in time and space, as they often cause new, unexpected situations, making them extremely difficult to manage. The present paper explores how applied human security could allow for a coordinated and secure allocation of population in emergencies. The use of new technologies could provide capabilities and tools for policy/decision-makers and first responders in order to facilitate such allocation endeavours. Cases demanding an organized evacuation in urban areas (large or small) are when disasters occur or are estimated as highly probable to happen in the near future. The identification of proper Emergency Assembly Points - EAPs plays a significant role in almost all crisis and disaster management situations, particularly in efficient and effective planning and responding.

Keywords: applied human security, geospatial profile, terrain analysis, disaster management, GIS

1 Savvas Chrysoulidis, Ph.D. Candidate, Department of Civil Engineering and Geomatics, Cyprus University of Technology (CUT), Greece, 0030 6972932936, E-mail: se.chrysoulidis@edu. cut.ac.cy

Issue 3 / 2019

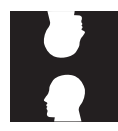

